\title{
Perivascular tumour balls in primary vitreoretinal lymphoma
}

\author{
Brijesh Takkar, ${ }^{1,2}$ Anubha Rathi, ${ }^{1}$ Nripen Gaur, ${ }^{1}$ Atul Kumar ${ }^{1}$
}

'Dr Rajendra Prasad Centre for Ophthalmic Sciences, All India Institute of Medical Sciences, New Delhi, India

${ }^{2}$ Department of Ophthalmology, All India Institute of Medical Sciences, Bhopal, MP, India

\section{Correspondence to}

Dr Brijesh Takkar,

britak.aiims@gmail.com

Accepted 2 December 2018

\section{DESCRIPTION}

A 60-year-old woman was referred to our clinic with a diagnosis of vitritis in both eyes (BE) that had been treated with oral steroids for more than 1 month. Visual acuity of BE was counting fingers close to face. Examination revealed $10-15$ cells/high power field in the anterior chamber of BE. Dense vitritis was noted and sonography did not show retinal detachment. Rest of eye examination was within normal limits. Blood count, chest X-ray, Mantoux test and peripheral blood smear were within normal limits. Screening tests for treponemal antigens and HIV were negative. No intracranial lesions were seen on MRI of head. With a presumptive diagnosis of primary vitreoretinal lymphoma (PVRL), $25 \mathrm{G}$ pars plana vitrectomy (PPV) and vitreous biopsy were planned for right eye (RE).

Vitreous biopsy was performed both before and after starting the infusion fluids under direct visualisation (figure 1). Dense exudation was noted in the foveal region along with perivascular white balls dispersed all over the posterior pole (figure 1). Flat subretinal infiltrates along with overlying necrotic retinal patches were noted in periphery. Subretinal biopsy was performed by injection and immediate aspiration of fluid through access retinotomy (figure 2). Thereafter, fluid air exchange was done followed by laser retinopexy of the retinotomy site and $\mathrm{SF}_{6}(18 \%)$ injected.

The biopsy specimens were immediately (within $5 \mathrm{~min}$ ) transferred to pathology laboratory where cytospin preparations made from the vitreous aspirate revealed large atypical lymphoid cells with moderately abundant cytoplasm and prominent nucleoli (figure 2). The cells were seen both singly and in groups. Immunocytochemical stains were strongly positive for the leucocyte common antigen (figure 2). However, they were negative for both $\mathrm{B}$ cell (CD 20) and T cell (CD 3, CD 5) markers.

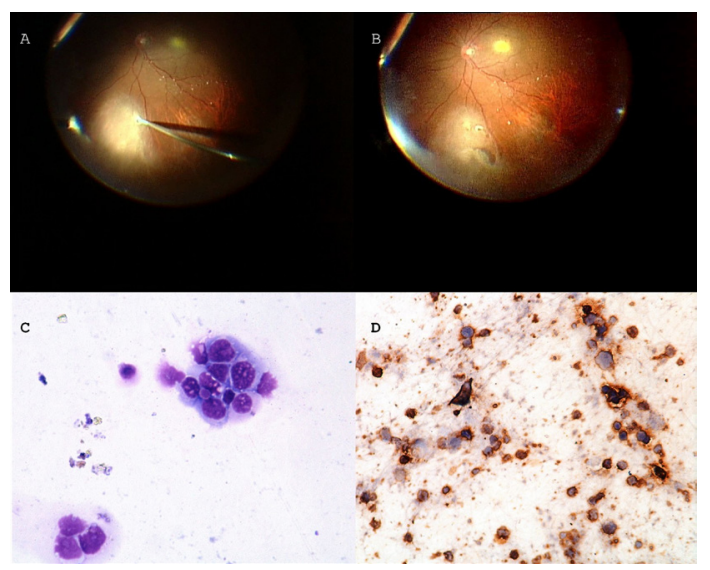

Figure $2(A, B)$ Intraoperative photograph under the wide angle viewing system depicting subretinal flat infiltrates. Subretinal biopsy is being performed through an access retinotomy by injection followed by immediate aspiration of fluid using soft-tipped cannula. (C) Cytospin smear of vitreous aspirate showing large atypical cells (May Grunwald Giemsa stain ×400). (D) Immunochemistry for leucocyte common antigen shows strong positivity $(\times 400)$.

Hence, a diagnosis of null cell PVRL was made and oncology consultations were done for cerebrospinal fluid (CSF) examination and chemotherapy. Fourteen days later, the retina was attached with a best corrected visual acuity (BCVA) of 4/60 in RE.

Ocular involvement without apparent central nervous system (CNS) involvement may be seen in around 20\% patients of intraocular lymphoma. While most cases are B cell non Hodgkin's lymphoma (NHL), null cell lymphoma has also been detected rarely. ${ }^{1}$ Vitritis and subretinal infiltrates are well-known presenting signs of PVRL. ${ }^{12}$ Although perivasculitis is rarely associated with PVRL, ${ }^{12}$
Check for updates

(C) BMJ Publishing Group Limited 2018. No commercial re-use. See rights and permissions. Published by BMJ.

To cite: Takkar $B$, Rathi $A$, Gaur N, et al. BMJ Case Rep 2018;11:e228006 doi:10.1136/bcr-2018228006

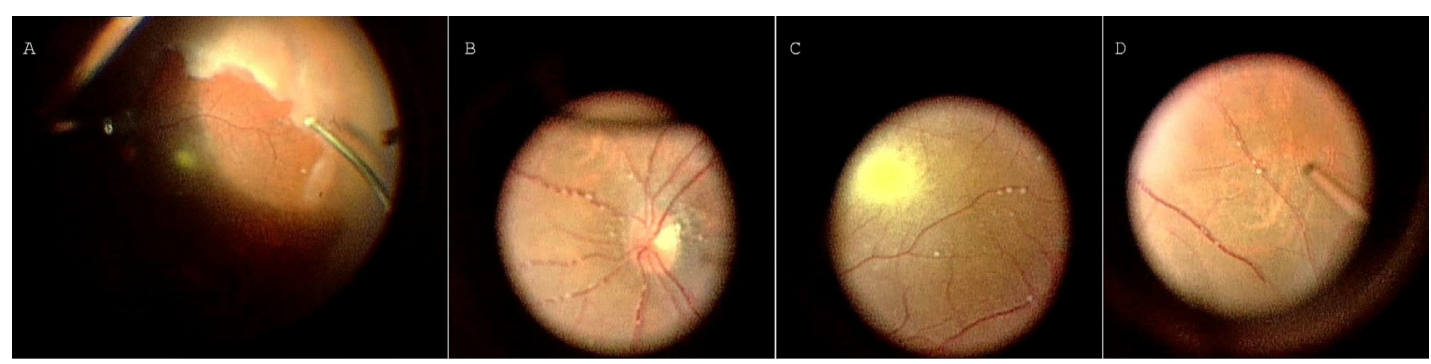

Figure 1 (A) Intraoperative photograph under the wide angle viewing system depicting vitreous biopsy being done through dense vitritis. (B)-(D) Intraoperative photographs under plano-concave contact irrigating lens depicting perivascular tumour balls noted all over the posterior pole. Dense yellow-coloured preretinal exudates were noted at fovea. 
perivascular tumour balls as found in our case have not been documented. This pattern of tumour dispersion may simply be due to an adherent posterior hyaloid along vascular arcades providing a scaffold for growth to rapidly dividing cells. During PPV, these tumour balls were found to be free of the vascular walls and were aspirated easily with very gentle passive suction for biopsy.

Diagnosis of PVRL is known to be delayed after presentation (as long as 60 months!). ${ }^{1}$ Clinical suspicion is highly paramount as is optimum cytopathological examination. Despite

\section{Learning points}

- Presumed vitritis unresponsive to immunosuppression should always be evaluated with a meticulous vitreous biopsy for ruling out masquerades.

- Presence of perivascular tumour balls should alert the surgeon and the pathologist to the possibility of primary vitreoretinal lymphoma. precautions like performing biopsy before and after switching on infusion fluid to avoid dilution, low cut rates for preservation of cellular details and rapid transfer of specimen to pathologist, multiple vitreous biopsies may be needed. ${ }^{3}$

Contributors BT and AK diagnosed the patient, and performed surgery. BT, NG and AR wrote the case report. BT and AK critically revised the text. BT is the overall guarantor.

Funding The authors have not declared a specific grant for this research from any funding agency in the public, commercial or not-for-profit sectors.

Competing interests None declared.

Patient consent for publication Obtained.

Provenance and peer review Not commissioned; externally peer reviewed.

\section{REFERENCES}

1 Char DH, Ljung BM, Miller T, et al. Primary intraocular lymphoma (ocular reticulum cell sarcoma) diagnosis and management. Ophthalmology 1988;95:625-30.

2 Velez G, Chan CC, Csaky KG. Fluorescein angiographic findings in primary intraocular lymphoma. Retina 2002;22:37-43.

3 Char DH, Ljung BM, Deschênes J, et al. Intraocular lymphoma: immunological and cytological analysis. Br J Ophthalmol 1988;72:905-11.

Copyright 2018 BMJ Publishing Group. All rights reserved. For permission to reuse any of this content visit https://www.bmj.com/company/products-services/rights-and-licensing/permissions/

BMJ Case Report Fellows may re-use this article for personal use and teaching without any further permission.

Become a Fellow of BMJ Case Reports today and you can:

- Submit as many cases as you like

- Enjoy fast sympathetic peer review and rapid publication of accepted articles

- Access all the published articles

- Re-use any of the published material for personal use and teaching without further permission

For information on Institutional Fellowships contact consortiasales@bmjgroup.com

Visit casereports.bmj.com for more articles like this and to become a Fellow 